\title{
BATHURST PLAINS AND BEYOND: EUROPEAN \\ COLONISATION AND ABORIGINAL RESISTANCE
}

\author{
Michael Pearson
}

The Bathurst Plains, located 150 kilometres due west of Sydney, were 'discovered' by Assistant Surveyor, George Evans, in December 1813, and in 1815 the first European settlement west of the Blue Mountains was established there. The colonisation of the Bathurst Plains and adjacent areas on the upper Macquarie River and Lachlan River tributaries incorporated reciprocal processes; the gradual modification of the coloniser's British land use pattern into a recognisably Australian pattern, and the gradual erosion, followed by the rapid collapse, of the Aboriginal land use pattern. ${ }^{1}$

The European colonisation of the Bathurst Plains elicited one of the strongest Aboriginal reactions met with to that date. The analysis of that resistance gives an insight into both the nature of Aboriginal settlement in the area, and the changes taking place in the European settlement pattern, and shows that while in some ways the Bathurst experience differed substantially from later conflict on the pastoral frontier in New South Wales, it does help to explain that subsequent contact history.

\section{ABORIGINAL SETTLEMENT PATTERNS, 1815-1824}

The reconstruction of Aboriginal settlement patterns as they existed at the time of the first European occupation of the Bathurst Plains is based largely on evidence from later periods, and is therefore to some degree tentative.

The early observations of Aboriginal settlement, before the 1824 violence, are of limited value in establishing patterns of occupation. Governor Macquarie was met by 15 Aborigines (men and boys) when he visited the tiny Bathurst settlement in 1815 . Captain Antill, a member of Macquarie's party commented that

... at first they [the Aborigines] appeared very much astonished at us, and not a

little alarmed at our reception, but in a short time by kind treatment they became more reconciled to us, and seemed to cast off all fear. Our people received strict injunctions to use them kindly, to put no restraint on their movements but to let them go and come when they thought proper. ${ }^{2}$

At this period unstudied observations of Aboriginal life-style were the rule, such as the comments by Lesson in 1824 that they were

Michael Pearson's doctoral research was a study of Aboriginal and early colonial land-use and settlement in the Upper Macquarie, New. South Wales. He now concentrates on historical archaeology as head of that department of New South Wales National Parks and Wildlife Service's Cultural Resources Section.

1 Elaborated in Pearson 1981.

2 Antill 1815:83. 
... true nomads, who have no fixed abode, but who for the most part follow the banks of the rivers and streams... Hence comes that absence of art and the wretched state in which they stagnate, especially when their primitive and barbarous customs are compared with the semi-civilisation of the happy inhabitants of the Polynesian Islands . . . ${ }^{3}$

Groups of up to 20 Aborigines were met with by early explorers and settlers in the area around Bathurst, and gatherings of 100 and 150 people were recorded on special occasions. ${ }^{4}$ The observations of James Gunther, the C.M.S. missionary at Wellington Valley from 1837 to 1843 , give a good picture of the nature of Aboriginal group movements and their frequency. 5 Gunther paints a picture of a highly mobile population and flexible group size.

The evidence given by these and other nineteenth century observers suggests that the upper Macquarie was inhabited by large localised groups of Aborigines, who in normal conditions of daily life were divided into small groups of up to twenty individuals. These small groups could coalesce relatively quickly into groups of from 80 to 150 people to take advantage of a guaranteed or desirable resource (such as seasonal food resources or the goods offered by the Wellington mission), for ceremonial or social obligations, or for special events (such as a pre-arranged gathering to see an explorer or first settler in an area). There seem to have been no over-riding seasonal factors affecting Aboriginal movements in the well-watered upper Macquarie.

The ethnohistoric evidence from the upper Macquarie suggests that recognisably distinct local communities existed, which were larger than the groups which were observed hunting and gathering at normal times. There is no direct evidence as to the size of these groupings, nor as to the extent to which their numbers were stable or fluid. An attempt, however, is made below to deduce the scale of the groups from ethnohistoric statements. There is also no evidence available to indicate that the 'boundaries' between the larger groups were fixed, or that they were even recognised as a concept. Again, the attempt below to draw lines between 'clans' is merely to differentiate the three areas that the ethnohistorical evidence suggests were inhabited by distinct groups. It does not imply that these lines necessarily represent actual boundaries.

In the ethnohistoric record, it would appear that it is the larger groups to which 'territories' were assigned. These larger groups correspond with Meggitt's 'community' unit' ${ }^{6}$ or with the 'clan' unit, the group who controlled their own land or 'estate'.7 The smaller self-sufficient groups are commonly referred to as 'bands', a number of which, as a group, constitute the clan or community. ${ }^{8}$ The terms 'clan' and 'band'

${ }^{3}$ Lesson 1824:158, 163, February 1824.

4 Cox 1821, 10 December; Lawson 1822, 23 January; 'Colo' 1826.

5 Gunther $1836: 41$.

6 Meggitt 1962:51.

7 Stanner 1965.

8 Peterson 1976:68. 
are used here in their loosest form, to differentiate between the larger and smaller groups referred to in the ethnohistorical record.

The local ethnohistorical sources use the term 'tribe' very loosely, obviously not to refer to the linguistic tribal grouping known as Wiradjeri, as this would imply a huge area of land including the whole of the upper Macquarie. Most of the references to 'tribe' probably refer to the large local groupings (clans), which, being seen by nineteenth century observers as separate entities from their neighbours, were labelled with the only commonly understood term for the primitive organisational unit the tribe.

Barron Field in 1822 recorded one of the first statements of territoriality in the Bathurst area:

Their numbers are diminishing. Not that they retreat before the settlements of Europeans, this they cannot do: the different tribes (few as their numbers are) would resist the invasion of each others territory. Thirty or forty miles will reach the circumference of each family's peregrinations. 9

'Colo' writing in 1826 agreed with Field's estimate of clan area:

It is difficult to ascertain the exact extent of each tribal area. I should suppose it does not exceed a radius of forty miles. ${ }^{10}$

'Colo' went on to suggest that eight 'tribes' lived in the area between Wellington Valley, the Coal River (the Hunter), and the Lachlan River. These 'tribes' were named for the part of the country they most frequently inhabited; they were the Parramatta or Bathurst tribe, Muc-are or Kings Plains tribe, Billabearra (Bellubula?), Wellington Valley, Bingum, Mudgy, Mundowry and Pialong tribes. However, another author (admittedly less reliable than 'Colo') claimed that in 1827 five 'tribes' existed in the Wellington Valley alone, split up into groups of 60 or 70 people. ${ }^{11}$ Other statements of the existence of 'tribal' (or clan) boundaries on the upper Macquarie were made by Henderson, Hale, Gunther, Meredith and Graham. ${ }^{12}$ Hood ${ }^{13}$ claimed that 'tribal areas' were $30-40$ miles square, with a population of 50 to 100 persons to each 'tribe'. Table 1 presents the evidence from five authors who make estimates of clan territory size. It will be noticed that these estimates vary widely and all can be challenged. Some, such as those of Hale and Strachan, are obviously far off the mark, and may be put down to unfamiliarity with the local area and its Aborigines. The more likely estimates appear to be those of 'Colo' and Field. Field perhaps came to his estimate by chance, but 'Colo' had a long association both with the local district and the Aborigines, having given a home on his property 'Brucedale' to some of the defeated leaders of the local 'Black War' of 1824 . The estimated size of these territories, where it is given by the sources quoted in Table 1, is usually in the form of an estimated distance to the boundary of the territory from a centre. The centre from which the radius of this territory is measured is never given as a geographical place, nor is it

9 Field 1822:432, 10 October 1822.

10 'Colo' 1826. 'Colo' was the nom de plume of George Sutton Jnr of 'Brucedale'.

11 Strachan 1870:229.

12 Henderson 1832:151-152; Hale 1846:109; Gunther nd; Meredith 1844:100; Graham 1863:113.

13 Hood 1843:157-8. 
ABORIGINAL HISTORY 1984 8:1

TABLE 1

Estimates of Clan Territory Size

\begin{tabular}{lcr}
\hline Source & $\begin{array}{c}\text { Estimated Size of } \\
\text { Territory in Miles }\end{array}$ & \multicolumn{1}{c}{ Area } \\
\hline Field (1822) & 30 mile radius & $7323 \mathrm{sq} \mathrm{km}$ \\
& 40 mile radius & $13019 \mathrm{sq} \mathrm{km}$ \\
'Colo' $^{-1826)}$ & $<40$ mile radius & $<13019 \mathrm{sq} \mathrm{km}$ \\
${\text { 'Colo' }(1826)^{\mathrm{a}}}^{\mathrm{a}}$ & 28 mile radius & $6475 \mathrm{sq} \mathrm{km}$ \\
Hale $(1840)$ & 50 mile radius & $20342 \mathrm{sq} \mathrm{km}$ \\
Hood $(1842)$ & 30 miles sq & $2331 \mathrm{sq} \mathrm{km}$ \\
& 40 miles sq & $4144 \mathrm{sq} \mathrm{km}$ \\
Strachan $(1827)^{\mathrm{b}}$ & 7 miles radius & $414 \mathrm{sq} \mathrm{km}$ \\
\hline
\end{tabular}

Original information supplied by each source is italicised.

a based on 'Colo's' claim of 8 'tribes' between Wellington, the upper Hunter catchment area and the Lachlan, an area of roughly $160 \times 125$ miles or $51800 \mathrm{sq} \mathrm{km}$.

b based on Strachan's claim of 5 'tribes' in the Wellington Valley, an area of at most $40 \times 20$ miles or $2072 \mathrm{sq} \mathrm{km}$.

given any special significance. Such statements of territory size use the radius as a convenient measuring stick only.

Further evidence on the nature of Aboriginal territories may be extracted from historic references to Aboriginal warfare, much of which seems to have been based on the defence of traditional land rights, Louisa Meredith, for example, claimed that warfare was often precipitated by the breaking of rigid laws relating to tribal boundaries, or by the inter-tribal abduction of women. ${ }^{14}$ Hood $^{15}$ believed that trespass was usually occasioned by hunting beyond the tribe's own ground, while Gunther, who spoke with more authority, claimed that though fights were often caused by trespass, more often they were over women. ${ }^{16}$ The territorial information comes from the identification of the antagonists on such occasions. Opponents included: a combination of the Mudgee and Wellington 'tribes' against the Castlereagh and Lower Macquarie 'tribes'; ${ }^{7}$ the Wellington 'tribe' against a more westerly 'tribe';18 the Mudgee 'tribe' against the Bathurst 'tribe';19 the Lachlan River 'tribe' against the Macquarie 'tribe' (i.e. Bathurst). ${ }^{20}$ These various reports suggest that three clans existed in the upper Macquarie, in the general areas around Bathurst, Wellington and Mudgee/Rylestone. These were surrounded by other clans, the Lachlan clan to the south-west, the Bogan clan to the west, Lower Macquarie clan to the north-west and

\footnotetext{
14 Meredith 1844:100-101.

15 Hood 1843: 158.

16 Gunther nd:43-4.

17 Gunther nd:45-6.

18 Henderson 1832:151.

19 Cox 1912.

20 Graham 1863:133-141.
} 


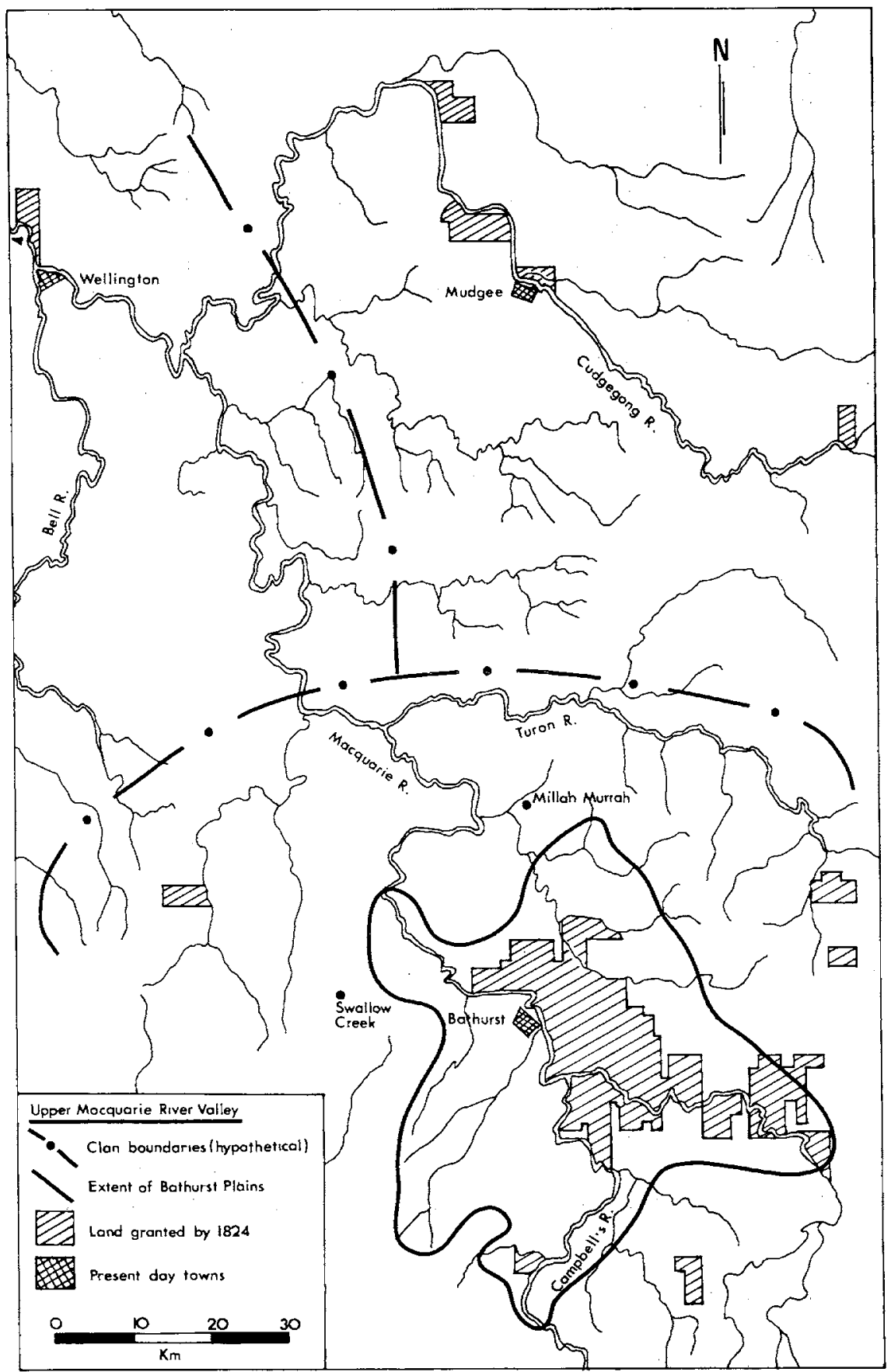

Figure 1 - The Upper Macquarie River Valley showing major tributaries, the location of the Bathurst Plains and hypothetical clan boundaries for the early nineteenth century. 
the Castlereagh clan to the north. These clans fought their neighbours at times, and at other times combined with them against a common enemy. The major causes of these conflicts were said to be trespass and abduction of women. It is worth noting that these two causal factors were in evidence in Bathurst in 1824 when martial law was declared. In Aboriginal terms, the Europeans were guilty of trespass and abduction on a grand scale, but unfortunately the traditional amicable solution to the conflict after a minimum amount of bloodshed was not part of the ground rules for the new cross-cultural conflict. It has been suggested that the European invasion of some areas of Australia caused Aboriginal groups to be more assertive about possession of clan territories; 21 I will argue later in this paper that such a response can be observed in the Bathurst area after 1821 .

The existence of three clan territories in the upper Macquarie is supported by evidence that three distinct dialects of Wiradjeri occurred. These dialects were used in areas around Wellington, Dabee/Capertee and Bathurst. ${ }^{22}$ The evidence from the various ethnohistoric sources suggests that these three territories may have had a radius of about $25-40$ miles $(40-64 \mathrm{~km}$ ), though they were not of regular shape. This tripartite subdivision of the upper Macquarie would help explain many of the unanswered questions regarding ethnographic observations of differing customs; it would also explain the regionalised pattern of Aboriginal-European aggression in the mid 1820's.

It has been hypothesised that natural boundaries may have separated the clan territories. If that is the case these boundaries for the upper Macquarie may have been the Turon River, the western edge of the Oberon and Hill End Plateaux, the Goulburn River and Talbragar River to the north, the Lachlan Valley to the south, the Great Divide to the east, and the Bogan River and the Plains to the west and north-west. Each of these three proposed clan territories occupies a drainage catchment area of one of the three main tributaries of the upper Macquarie. As Peterson ${ }^{23}$ has pointed out drainage basins appear to have an important bearing on the location of cultural boundaries in other parts of Australia.

The population for the upper Macquarie (above Dubbo), based on various estimates might have been between 500 and 600 at contact. This gives a population density of from $1: 41 \mathrm{~km}^{2}$ to $1: 35 \mathrm{~km}^{2}$, falling between the densities estimated for the Northern and Southern Tablelands of New South Wales by Flood. ${ }^{24}$

\section{EUROPEAN SETTLEMENT PATTERNS 1815-1824}

The pressures which drove the infant English colony clustered around Port Jackson to venture over the Blue Mountains have been closely studied by Perry and others. ${ }^{25}$ Perry suggests that the expedition of Blaxland, Lawson and Wentworth in 1813 was

\footnotetext{
21 Reynolds 1982:66.

22 Gunther nd:64-55.

23 Peterson 1976: passim.

24 Flood 1976:39.

25 Perry 1953-5; 1957; 1963; Jeans 1972.
} 
prompted by the loss of stock carrying capacity in the Cumberland Plains due to a deterioration in natural pasture, overstocking, a series of droughts and a plague of caterpillars. It was not the lack of available land, but the shortage of adequate fodder which made the discovery of new grazing lands a necessity. ${ }^{26}$

The settlement of the Bathurst Plains in 1815 with the Government Stock Establishment was Macquarie's response to this need. ${ }^{27}$ However it remained a tightly government controlled settlement as regards land, labour and markets. Convicts provided labour, and access by other than government officials was restricted.28 Stock could be grazed under permit by a few, but land was not open to occupation. This deliberately restrictive policy established by Macquarie ensured that the Bathurst Plains remained the 'government grazing frontier' and that growth until 1822 was slow. It also minimised cross-cultural conflict and competition for land and its resources.

The impact on Aboriginal traditional life made by the European settlement of the relatively small area settled up to 1821 appears to have been slight. Most of the Bathurst Plains was visited on a non-permanent basis by free-ranging flocks seeking good grazing, requiring few permanent stock-keeper's structures and few fences or yards. Also, the small European population was living off the commissariat, which provided few incentives to lure Aborigines from a traditional lifestyle, and reduced the European demand on the local game, at least for a time. The presence of an unusual community in their midst may not have disturbed the Aboriginal view of the ability of the district to continue to support their own economic system, but increased aggression in the early 1820's may mark the awakening in Aboriginal consciousness of the real threat the Europeans posed to their continued use of traditional lands, and to the realisation that Europeans did not share Aboriginal views on reciprocity.

The crucial period in the development of the Macquarie Region frontier was the decade after Governor Macquarie's departure in 1821. In this period land grants were made for the Bathurst area and Cudgegong district to individuals, ensuring land tenure. In addition Government holdings also increased, with a number of new Government Stock Stations opened, such as the Wellington Agricultural Station of 1822 to 1831 . All these changes had implications for Aboriginal/settler relations.

\section{WHITE COLONISATION AND BLACK RESISTANCE, 1822 to 1825}

In the period 1815 to 1822 , then, two land settlement regimes were in force on the upper Macquarie, one expanding at the ultimate expense of the other. The Aboriginal pattern, it is hypothesised from the ethnohistoric record, consisted of the division of the region into three 'clan' territories, centred at Wellington, Mudgee/Rylestone and east, and Bathurst. These three territories shared the estimated 500-600 Aboriginal inhabitants at contact. The primary economic resource zones in each territory were the mired woodland/grasslands which skirted the Bathurst Plains and predominated in the Bell River Valley above Wellington and the Cudgegong River flats and upper Capertee Valley around Mudgee.

26 Perry 1963:27-29; 1957:4.

27 Ritchie 1971, vol. 1:178, Blake's evidence.

28 Macquarie 1815:72-3; Field 1822:134. 
The European settlement pattern up to 1822 consisted of the open-range grazing of sheep, carried out by a small population concentrated on Bathurst, numbering 287 by 1821. This land-use regime resulted in little modification of the Bathurst Plains as a whole, due mainly to Macquarie's policy on land alienation. There was minimal fencing and few other improvements; little conflict with the Aboriginal land-use regime emerged. In the early 1820 s a series of events reflected important changes in the settlement patterns of both Aboriginal and European societies of the upper Macquarie. The events outlined below were symptoms of reciprocal processes; the expansion of European grazing inside the Bathurst Plains, and the rapid reduction in the area of land available to Aborigines for traditional land-use.

European grazing was disrupted by wandering groups of Aborigines who disturbed flocks and herds and who occasionally hunted domestic animals as well as wild ones. Stockmen were often disconcerted by meeting armed groups of Aborigines while miles from the support of other Europeans. The Aboriginal practice of burning off was also considered undesirable with so many scattered flocks and herds. These problems were mainly minor irritations; but many Europeans saw no reason to put up with the 'nuisance' caused by Aborigines. The Aborigines began to see similar problems. Their traditional lifestyle was threatened in a very real way by the European presence. Stock and stockmen disturbed game, and disrupted hunting and gathering activities. Fences broke up the land and made traditional land-use difficult. Guns were owned by the Europeans which were far more effective against game than were spears, and put the European in direct competition with the Aboriginal for the rapidly dwindling game numbers.

Fried ${ }^{29}$ has isolated three factors which affect the outcome of a meeting between two cultures. First, geography, the spatial distribution of natural features, influences the intensity and continuity of culture contact. In New South Wales, the inability, or more likely the lack of incentive, to cross the Blue Mountains, protected the Macquarie Aborigines from contact with Europeans for nearly thirty years. Also, partially because of geography, the Bathurst settlement was stagnant for the first five years of its existence. Once settlement commenced in earnest, the geographical distribution of natural resources meant that the Europeans were primarily interested in only three areas ideal for grazing in the upper Macquarie, the Bathurst Plains, Cudgegong Valley and Bell River Valley. Unfortunately these areas appear to have been of major importance to the Aboriginal economy as well.

Fried's second factor is ecology, 'the interaction of man as a cultural animal with his environment through the medium of technology'. Here there was no point of mutual interest between Europeans and Aborigines. Aborigines lived with a very simple technology, but backed up by an expert knowledge of their environment. Europeans on the other hand had a complex technology which to a degree allowed then to modify the unfamiliar environment to meet their needs. There was nothing that the Aboriginal could contribute to the European economy which would give their society a place in the new regime. Aboriginal culture was therefore given no value at all on the frontier. 


\section{BATHURST PLAINS AND BEYOND}

The third factor affecting cultural contact is social organisation, especially in terms of land tenure. As Spoehr ${ }^{30}$ points out a society interprets its resources within the framework of its own social structure. To the European mind, the Aborigines had no actual tenure over the land, as Aboriginal social organisation imposed a form of land 'ownership' so different from that of the Europeans as to go unrecognised by them. Aborigines were seen as 'nomads' with no fixed abode; therefore they had no land rights. The nature of their social organisation left the Aborigines virtually powerless to retaliate to invasion in a collective way. On the other hand, the failure of Europeans to recognise Aboriginal social structure led to their unwitting breach of Aboriginal laws and vice versa. This often resulted in bloodshed and retaliation in the form of guerilla warfare, which the European settlers found difficult to counter.

Despite the enormous differences between the two cultures and the growing economic competition between them, it took eight years for race relations to deteriorate to the point where open conflict was inevitable. Macquarie's official attitude to Aborigines has been analysed and reduced to four points by Bridges: ${ }^{31}$.

(i) subjugation and conciliation

(ii) encouragement and help to become farmers and fishers

(iii) extension of European influence through tribal leaders

(iv) recognition of those who helped Europeans

It would appear that Macquarie was successful only in subjugation.

As with many policies thrown up by the Colonial Government, Macquarie's plans for Aboriginal conciliation had little practical effect out on the frontiers where the contact between the races occurred. However, Macquarie's policies restricting expansion of settlement at Bathurst kept racial strife to a minimum. Occasional attacks (such as the spearing of William Lawson's best brood mare in 1819) did occur, ${ }^{32}$ but it was not until the accelerated expansion of the early 1820 's that the situation became serious. The European population of the district in 1820 stood at only 114 persons; this had trebled to 392 in 1822 . By 1824 , the worst year of racial strife, the population of Bathurst district had rocketed to 1267 persons. The amount of alienated land and numbers of stock increased proportionately. Alienated land increased from 2,520 acres in 1821, to 91,636 acres in 1825 in the Bathurst district. Combined numbers of sheep and cattle increased from 33,733 in 1821 , to 113,973 in 1825. ${ }^{33}$ This rapid increase to some degree reflected the overall increase in the colony's population, which had reached 33,595 in 1824 , but was primarily influenced by the change in policy towards settlement at Bathurst after Macquarie left in 1821 . This is clearly seen in the increase in the area of alienated land by a factor of 36 times.

These changes between 1820 and 1824 proved critical to the continuance of the Aboriginal lifestyle in the Bathurst area. Friction was inevitable. Contact between the expanding Europeans and the Aboriginal society on the retreat became unavoidable. Aborigines learnt the value of European goods, developed a growing dependence on

30 Spoehr 1956:97.

31 Bridges 1966:256.

32 CSIL 1819, Hassall to Macquarie, 16/6/1819 (AONSW 4/1742).

33 Compiled from relevant $H R A$ volumes and NSW Returns. 
European food, and sought ways of acquiring these. With the disruption of native game on the plains, the use of European stock for food became a temptation which most Aborigines saw little reason to refuse. The European stockmen on the other hand had increasing difficulty maintaining control over expanding flocks and herds, which was not lessened by the Aboriginal practice of 'rushing' stock. In a heavily male-dominated society, convict stockmen and Aborigines alike saw a chance for a primitive barter system, exchanging European goods for the favours of Aboriginal women. Excesses by either party, such as Aborigines stealing goods or spearing cattle, or stockmen abducting or raping women, or otherwise maltreating Aborigines, led to retaliation by the other side. This exchange of women for goods has been seen in other parts of Australia as an attempt by Aboriginal groups to involve Europeans in the Aboriginal system of reciprocal obligation, the misunderstanding of which could also lead to conflict. ${ }^{34}$

Perhaps the immediate cause of the 1823-24 'war' can be found in the coincidence between the area settled by Europeans in 1824 and the area of one of the three Aboriginal clan territories identified earlier. The spread of European settlement, as shown in Map I, had, by 1824, covered most of the cleared and semi-cleared land in the Bathurst Clan territory. While this area had probably been grazed by European stock for some years prior to 1824 , it was then that European ownership, rather than mere use, was being stressed. Claims of ownership were reinforced by the fencing of pasture land, increased stock numbers, an expanding European population, and the exclusion of Aboriginal land-use techniques. While there appears to have been reasonably flexible movement of one clan into the territory of adjacent clans (as noted above) it is unlikely that flexibility would have extended to absorbing the whole of a displaced clan. It is therefore likely that the progression between 1822 and 1824, from reasonably compatible low-key land-use by Europeans to the exercise of exclusive proprietorial rights over a large and vitally important part of the territory of the Bathurst clan, forced the Bathurst clan to retaliate as best it could.

Coinciding with the rapid filling of the Bathurst Plains by European stock was the drought of 1822-4 which would have put pressure on both Aboriginal and European land-use techniques and probably contributed to the breakdown of already strained relations between the races. ${ }^{35}$ The final collapse of good relations can be dated from 1822. In April 1822, William Lawson reported the murder of a convict named William Maybow, by the 'natives'. Lawson, however, thought that there must have been some provocation for this act. ${ }^{36}$ In October of the same year Barron Field rode to the west of Bathurst and

returned by the huts of a sheep-location, and found them deserted by reason of a recent plunder on the part of the native Indians. These and a few accidents more

34 Ryan 1982:67-9; Reynolds 1982:70-72.

35 It is worth noting in this regard that the trouble in the Cudgegong Valley to the north may have been a reaction by local Aborigines after seeing in their own clan territory the beginnings of what was happening in Bathurst. However, in the Wellington area, where European settlement was still very scattered and low-key, no aggression occurred. CSIL Bathurst 1815-23, Lawson to Goulburn, (AONSW Reel 598:135-8). 


\section{BATHURST PLAINS AND BEYOND}

serious will happen till the natives become more domesticated among the settlers themselves (their servants don't know how to treat them); but their thefts are generally confined to a tomahawk or an axe, the temptation of possessing which is too irresistible for black human nature. But the aborigines of this new country very rarely appear in combined numbers; and are easily scared by guns, horses, or even English dogs. ${ }^{37}$

Governor Brisbane followed Macquarie's policy regarding the Aborigines, or so it would appear from the instructions given to Percy Simpson for the establishment of the Wellington Government Station in January 1823:

You will take an early opportunity of establishing a friendly intercourse with the neighbouring Blacks. Whenever they apprehend stray cattle or Runaways, small presents are to be made to them of wheat, Tomahawks, or Fish hooks, and you are to punish very severely any ill treatment of them..$^{38}$

However, events at Bathurst were compounding, showing that policy and practice in this case were incompatible. John Maxwell, Superintendent of Government Stock at Bathurst, reported that Aborigines were becoming troublesome at the Swallow Creek station, between Bathurst and the site of the present town of Orange, in August 1823. By November, Maxwell had to report the abandonment of the Swallow Creek station 'on account of the Hostile Natives'. Two stockmen had been killed at Marsden's property nearby the week before, and Maxwell's men refused to work. ${ }^{39}$

In October 1823 Judge Wylde's overseer report trouble near Bathurst, with the spearing of cattle belonging to Wylde and G.T. Palmer. Huts had also been robbed of provisions at Wylde's run at King's Plains. Lawson kept control over the European reaction to the situation by sending out one of Wylde's overseers with four soldiers. His instructions were as follows:

You will proceed with four soldiers and a party of prisoners in pursuit of the hostile black natives, and in the event of your falling in with Jingler's tribe, you are not to fire upon them, only in case of actual necessity in self defence, but to secure as many of them as possible and to bring them before me to be dealt with according to law, and you are to be very particular not to offer any violence to the native Women, or destroy them or their children.40

Wylde himself reported the affair to Goulburn in November, stating that in a skirmish at a hut one Aboriginal was shot dead. His men then deserted the run in fear for their lives. Wylde requested immediate military protection. ${ }^{41}$ There is no evidence that Lawson's hunt located any Aborigines connected with the Wylde incident, but Lawson himself remained unconvinced that the recent outbreaks of violence were one-sided. Reporting on the killing of the two men on Marsden's property, he wrote: 'I have

37 Field 1822:135.

38 NSW Governors Despatches 1832-5: Colonial Secretary to Simpson 1/1/1823 (A 1297-13:1363).

39 CSIL Assignment \& Employment of Convicts 1800-1819 Letter 21/8/1823 (AONSW Reel 593); CSIL Bathurst 1815-1823, Maxwell to Goulburn 26/11/1823 (AONSW Reel 598:315-17).

40 CSIL Letter 12/10/1823 (AONSW Reel 598:337).

41 CSIL WyIde to Goulburn 19/11/1823 (AONSW Reel 598:311-13). 
not yet learnt the causes, but I fear the white persons in the first instance have been the aggressors ... 42

Lawson resigned his post as Commandant at Bathurst late in 1823. The new commandant, Morriset, was more open to pressure from Judge Wylde, who not only called for a military operation, but also suggested that a reward be given to the tribe that turned-in 'Saturday' (Windradyne), identified as one of the leaders in recent troubles. ${ }^{43}$ Morriset sent a small military force to follow up a report of cattle spearing on the eastern side of the Macquarie in December. A couple of Aborigines were taken prisoner. Although it could not be shown that they had anything to do with the spearings, Morriset thought that the fright would do them good. ${ }^{44}$

The Sydney Gazette of 8 January 1824 reported on the recent disturbances at Bathurst, and on the capture of 'Saturday' - 'one of the Chiefs of a desperate tribe', who was arrested and put in chains for a month. The Gazette found it of light comic relief to point out 'the natives urge that the white men have driven away all the kangaroos and oppossums, and that black men must now eat beef!' Amusing as this may have appeared to the editors of the day, there was more truth to the claim than the writer knew.

In January and February 1824 Judge Wylde's cattle were again attacked; he once more called for military action. ${ }^{45}$ It seemed that this time his demands were met. Nelson Lawson, son of William Lawson, noted in April two obviously related observations: 'The natives is [sic] very troublesome over the mountains, there has been several of them shot and two of them committed ... to the criminal court, and is likely to be hanged ... The time passes very pleasant over the mountains. The sport is getting very scarce . . 46 Referring to the same incident, Nelson's brother, William Inr, wrote 'there has been several [Aborigines] recently shot by soldiers which were stationed at the Judges station ... We have now commenced hostilities against them in consequence of their killing a great number of shepherds and stockmen, but afraid we shall never exterminate them, they have such an extensive mountainous country for them to flee from their pursuers. The party which is in quest for them fell in with a horde of their women and dispatched them in return for the men, they are in guard of the city . . ${ }^{47}$ This last sentence is confusing, but it appears to mean that women were being held hostage for the men's surrender, not that the women were killed.

The reason for this manhunt, referred to by the Lawsons, was the killing of seven stockkeepers in two days in May 1824. One man was killed by a group of Aborigines at a mill near Bathurst. The group then went on to 'Millah Murrah' near Wyagdon, where three stock keepers were killed, and to 'Warren Gunyah' at Wattle Flat, where

42 CSIL Lawson to Goulburn 27/11/1823 (AONSW Reel 598:319).

43 Wylde to Goulburn 1/12/1823 (AONSW Reel 598:335).

44 CSIL Morriset to Goulburn 26/12/1823 (AONSW Reel 598:373-4).

45 CSIL Wylde to Goulburn 22/1/1824 (AONSW Reel 1257:3-5).

46 Beard 1967:34.

47 Beard 1967:37-8. 
three more stockmen were killed. 48 This particular series of attacks may have been related to the building of the homestead at 'Millah Murrah' on, or near to , a ceremonial ground. Further, a rumour was current that poisoned flour had been given to local Aborigines there. 49

Also in May, Hassall's property on O'Connell was attacked, and a stockman badly wounded. A revenge party of stockmen were reported to have killed three Aboriginal women near 'Raineville', which led to a trial in Sydney of five men on charges of manslaughter. All of them were acquitted.50 Four more stockmen were killed on Lawson's property at Cambell's River after July.51 Reports of retribution killings were, for obvious reasons, less exact than reports of Europeans killed. However, rumours reached Sydney of massacres of up to 60 or 70 Aborigines, although the Sydney Gazette preferred to believe that only eight or nine Aborigines had been killed.52 Reverend Walker believed that at least 100 Aboriginal men, women and children had been killed in 1824;53 massacres were reported at Billiwillinga, Wattle Flat, Capertee and Clear Creek, but no details recorded. 54

Attitudes towards Aborigines were hardening, even in official circles. On 10 June 1824 , Governor Brisbane requested of the Colonial Secretary, Bathurst, that a troop of colonial cavalry be raised 'not only with a view of keeping the Aborigines in check against whom Infantry have no chance of success, but also for the general Police of the Country'. The strength of the troop was to be 29 men and three officers. 55 This was the foundation of the Mounted Police.

Feelings were running very high in Bathurst, and at a Public Meeting, William Cox is reported to have argued that 'the best thing that could be done, would be to shoot all the Blacks and manure the ground with their carcases, which was all the good they were fit for! It was recommended likewise that the women and children should especially be shot as the most certain method of getting rid of the race'.56 The petition from this meeting, signed by William Cox, Robert Lowe, William Lawson, Archibald Bell, G.T. Palmer, John Wylde, Samuel Marsden and others, demands: that in as much as the Black Natives are understood to be still found collected in numbers and so advancing upon various cattle stations to the great hazard of life and property, such a large Military Force be sent out . . . as may at once overawe the natives and lead to the hope by taking prisoners, or otherwise, of bringing them at once to a state of due Subjection and Innoffensiveness. ${ }^{57}$

48 CSIL May 1824 (AONSW Reel 1257:29-30); Sydney Gazette 10/6/1824; Horton 1825: 1359-1360.

49 Salisbury \& Gresser 1971:23.

50 Salisbury \& Gresser 1971:26; Sydney Gazette 10/6/1824.

51 Salisbury \& Gresser 1971:26; Fisher T. 1824.

52 Sydney Gazette 22/7/1824.

53 Bonwick Transcript Box 53:1433.

54 Suttor 1887; Salisbury \& Gresser 1971:31.

55 Governors Despatches, Brisbane to Darling 10/6/1824, Vol. 5:555-7.

56 Gunson 1974, Vol. 1:49.

57 CSIL 16/7/1824 (AONSW 4/1799:74-5). 
Governor Darling finally took decisive action, proclaiming Martial Law west of Mt York, on 14 August 1824.58 Under this authority a vigorous military campaign was launched against the Aborigines of the district. The first major incident occurred when about 30 Aborigines attacked and drove off a large herd of cattle, belonging to Cox, in the Mudgee district. A battle broke out between three of Cox's men and the Aborigines, in which it was claimed that 16 Aborigines were killed. The Bathurst Commandant, with four magistrates, forty soldiers and six settlers raced from Bathurst in pursuit. The Gazette comments that 'there is every reason to hope that they will come up with the natives, and put an end to this sanguinary and desultory warfare'. ${ }^{59}$ However, one of the magistrates, George Ranken, wrote on 28 September that groups of soldiers had been sent in different directions but 'None of us succeeded in seeing the enemy, except Walker, and that was only in the shape of one black gin and a picanniny'.60 Other reports suggest some other groups of soldiers did make contact with Aborigines. Threlkeld claimed that one group was driven into a swamp where all were shot, after which 45 heads were cut from the bodies, boiled down, and the skulls taken back to Britain by Commandant Morriset as souvenirs. ${ }^{61}$

In marked contrast to the situation in Bathurst and Mudgee was the peace which reigned at Wellington Valley. The Sydney Gazette reported that while 'an exterminating war' was being pursued at Bathurst, the kind treatment shown the Aborigines at Wellington had led to a harmonious coexistence. Wounded Aborigines from Bathurst occasionally turned up at Wellington for medical help. ${ }^{62}$ The real factor of importance at Wellington, besides good relations with the Government station there, was that only a small percentage of the land had been taken over by Europeans when the Bathurst hostilities broke out. This, and the small numbers of Europeans in the district, meant that the shock of land alienation was delayed for at least a decade. In addition, because of the long association with Europeans, and the ameliorating role the mission played in the Aboriginal economy, the impact of contact took a different, mainly non-violent form.

Meanwhile, the Bathurst and Mudgee Aborigines, despite the importance the Europeans placed on 'Saturday' (Aboriginal name 'Windradyne'), and 'Jingler' (Aboriginal name 'Morall'), lacked cohesive leadership and organisation. The identified 'leaders' of the 'uprising' were probably in fact leaders of individual bands, who happened to be particularly effective at organising their groups in guerilla warfare. It would seem unlikely that the Bathurst clan as a whole could gather in large enough numbers to be co-ordinated by a single overall leader once hostilities broke out in earnest. A counter-attack as a unified group was made impossible by continued European harassment which kept groups scattered and small. These small bands escaped into the gorge country of the Capertee, Turon and Abercrombie Rivers when the European offensive reached its peak. Subsistence in these areas was hard, and,

\author{
58 Sydney Gazette 19/8/1824. \\ 59 Sydney Gazette 16/9/1824, 30/9/1824. \\ 60 Ranken 1916:20. \\ 61 Gunson 1974, Vol. 1:49. \\ 62 Sydney Gazette 14/10/1824.
}


as Governor Darling put it, the Aborigines were kept 'in a constant state of alarm'.63 Gradually, as the situation eased, groups emerged from hiding and began to arrive in Bathurst in increasing numbers, although 'Saturday, who has rendered himself so. notorious in the aboriginal annals, still thinks it prudent to keep out of reach, and has not even been heard of'.64 However, even the mighty 'Saturday' had a limit to the amount of hiding he could endure, and his presence was noted with some awe at the Parramatta Blanket Feast on 25 November 1825.65 The situation having calmed down, the Martial Law Proclamation was repealed on 11 December 1824, four months after its introduction.

Despite the relatively rapid collapse of Aboriginal opposition to European expansion, some short term effects were felt. The abandonment of the Swallow Creek Government station has been noted, and the desertion of stockmen from many of the Bathurst properties was a common occurrence in 1824. The 'war' coincided with over-stocking and bad seasons at Bathurst, which encouraged further extension of settlement to new areas. This movement, however, was thwarted for a time. As William Lawson Jnr noted We would have sent our wether flock further into the interior if the aborigines were inclined to be peaceable'.66

On the northern extension of settlement, at Mudgee, Cox met with reversals. Much of his stock had been moved to 'Gunatawang', north of Mudgee, in 1824, but extreme aggression on both sides led to the abandonment of the run in early 1825 . Expansion northwards was stopped, at least for a while, but Cox simply moved the stock east, (to 'Rawdon' in the Rylestone district) where Aboriginal opposition was less effective. 67

Estimates of loss of European lives vary. The 'official' toll was 19,68 but by counting up individual reports the number comes to at least 22. The toll of Aboriginal lives is impossible to calculate. It was estimated by some as being 'over 100'; however it may have considerably exceeded this figure. The Bathurst clan never recovered from this population loss. Their subsequent decline was accelerated by the despair consequent on the loss of land, kin and traditional lifestyle, and the ravages of European diseases and the poor conditions attending their acquired position at the very bottom of the new social order.

In the decades following the 1824 war, a few cases of renewed Aboriginal aggression were noted, such as the killing of cattle at Wellington in 1835 (in response to the abduction of women) ${ }^{69}$ or the killing of a shepherd and 80 sheep at 'Bimbijong' near Mudgee in $1840.0^{\circ}$ Yet most references are to vaguely reported

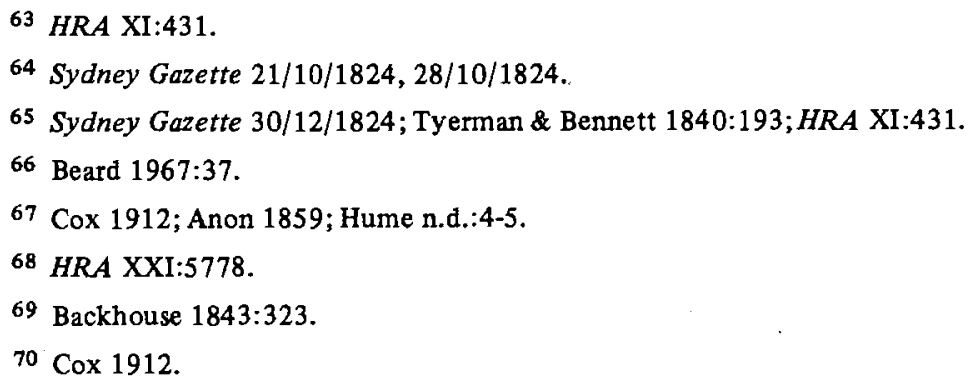


massacres of Aboriginal groups by Europeans. Reverend Gunther, from the Wellington Mission, claimed in 1841 that extermination by violence occurred more often than was commonly known, and that the rest of the Aborigines were being taken off by drunkenness and debauchery. ${ }^{71}$ Other massacres were reported in the Mudgee-Rylestone area. ${ }^{72}$

In conclusion, we can see that, in the Bathurst Plains/upper Macquarie River area at least, the onset of aggression on the part of both Aboriginal and European was a response not to the arrival of European land-use, but to its escalation to the point where it was incompatible with the viable continuation of the traditional Aboriginal land-use of one clan group. Eight years of comparatively peaceful coexistence was followed by two years of violence. An as yet untested hypothesis based on observations of subsequent contact conflicts on the pastoral frontier beyond Bathurst, is that the reaction of both Europeans to Aboriginal groups and Aboriginal groups to European graziers, was to some degree based on the Bathurst experience; and that the reaction time between first settlement of an area and the period of racial conflict was reduced. This response was probably partly due to the European perception that land-use conflict with Aboriginal groups was inevitable and partly to the Aboriginal perception that the coming of graziers claiming land ownership was a direct and immediate threat to their traditional land-use. These lessons were learnt at Bathurst.

71 HRA XXI:737; Gunther's report of 1841.

72 Armstrong 1905.

\section{BIBLIOGRAPHY}

Antill, H.C. 'Journal of an excursion over the Blue Mountains or Western Mountains of N.S.W. to visit a tract of newly discovered country in company with Governor Macquarie etc' in Mackaness G. ed. Fourteen journeys, 77-90.

Armstrong. W.W. Some early recollections of the town and districts of Rylestone. MS. 1905 in Mitchell Library, Sydney.

Backhouse, J.A. Narrative of a visit to the Australian Colonies. London, 1843.

Beard, W. ed. Old Ironbark: some unpublished correspondence (1817-24) from and to William Lawson, Explorer and Pioneer of Veteran Hall, NSW. Sydney, 1967.

Bonwick Transcrip ts.Manuscript transcripts of official reports, Mitchell Library, Sydney.

Bridges, B.J. Aborigines and white relations in New South Wales 1788-1855. Unpublished M.A. Thesis, University of Sydney, 1966.

'Colo'. Letter in The Australian 14 October 1826.

Colonial Secretary - In Letters (C.S.I.L.) Manuscripts in Archives Office of N.S.W., Sydney.

Cox, G. Journal kept by Mr. George Cox on his late tour to the Northward and Eastward of Bathurst etc. MS in Mitchell Library, Sydney dated 1821.

Cox, G.H.F. History of Mudgee. MS. 1912 in Mitchell Library, Sydney.

Evans, G. 'Assistant Surveyor Evan's Journal, 1813-14' in Mackaness G. ed. Fourteen journeys, 17-32.

Field, B. 'Journal of an Excursion Across the Blue Mountains of N.S.W. in 1822' in Mackaness G. ed. Fourteen journeys, 118-142.

Fisher, T. Fisher to Hassall, 20/7/1824, Letter in Hassall Correspondence, vol.3, MS. Mitchell Library, Sydney.

Flood, J. 'Man and ecology in the Highlands of Southeastern Australia' in Peterson, N. ed. Tribes and Boundaries in Australia. Canberra, 1976:30-49. 


\section{BATHURST PLAINS AND BEYOND}

Fried, M.H. 'Land tenure, geography and ecology in the contact of cultures'; The American journal of economics and sociology, 11, 1952:391-412.

Graham, J. ed. Lawrence Struilby: or observations and experiences during twenty-five years of bush life in Australia. London, 1863.

Gunson, N. ed. Australian reminiscences and papers of L.E. Threlkeld. 2 vols. Canberra, 1974.

Gunther, J. Joumal 1836-41. MS. in Mitchell Library, Sydney.

'Lecture on the Aborigines of Australia' n.d. MS in Mitehell Library, Sydney.

Hale, H. United States exploring expedition during the years 1838-42. 4 vols. Philadelphia, 1846.

Henderson, J. Observations on the colonies of New South Wales and Van Dieman's Land. Calcutta, 1832.

Historical Records of Australia, Sydney.

Hood, J. Australia and the East, being a journal narrative of a voyage to NSW etc. in the year 1841-2. London, 1843.

Horton, W. Extracts from Journal 1825. Bonwick Transcripts, vol. 4:1357-61. MS in Mitchell Library, Sydney.

Jeans, D.N. An historical geography of New South Wales to 1901. Sydney, 1972.

Lawșon, W. Expedition from Bathurst to Cudgegong etc. 1822. MS in Mitchell Library, Sydney.

Lesson, R.P. 'Journal across the Blue Mountains in 1824', in Mackaness G. ed. Fourteen journeys. . . : 143-165.

Mackaness, G. ed. Fourteen joumeys over the Blue Mountains of New South Wales, 1813-1841. Sydney, 1965.

Macquarie, L. 'Tour over the Western or Blue Mountains', 1815. in Mackaness, G. ed. Fourteen journeys. . : :64-73.

Meggitt, M.J. Desert People. Sydney, 1962.

Meredith, Mrs C. Notes and sketches of New South Wales: during a residence in that colony from 1839-1844: London, 1844.

N.S.W. Governors Despatches Various MS in Archives Office of New South Wales.

Pearson, M. Seen through different eyes: changing land-use and settlement patterns in the upper Macquarie River. Unpublished PhD Thesis, Australian National University, Canberra, 1981.

Perry, T.M. 'The spread of rural settlement in New South Wales 1788-1826', Historical studies, 6(1953-5):377-395.

- 'Climate, caterpillars and terrain', Australian geographer, 7, 1957:3-14. Australia's first frontier. Melbourne, 1963.

Peterson, N. 'The natural and cultural areas of Aboriginal Australia' in Peterson, N. ed. Tribes and boundaries in Australia. Canberra, 1976:50-71.

Ranken, Mrs W.B. The Rankens of Bathurst. Sydney, 1916.

Reynolds, $\mathrm{H}$. The other side of the frontier. Ringwood, 1982.

Ritchie, J. The evidence of the Bigge Reports, 2 vols. Melbourne, 1971.

Ryan, L. The Aboriginal Tasmanians. Brisbane, 1982.

Salisbury, T. and P.T. Gresser. Windradyne of the Wiradjeri: Martial Law in Bathurst 1824. Sydney, 1971.

Spoehr, A. 'Cultural differences in the interpretation of natural resources' in Thomas, W.C. ed. Man's role in changing the face of the earth. Chicago, 1956.

Stanner, W.E.H. 'Aboriginal territorial organization, state, range, domain and regime', Oceania, 36(1965):1-26.

Strachan, A. The Life of Rev. Samuel Leigh. London, 1870.

Suttor, W.H. Jnr. Australian stories retold and sketches of country life. Bathurst, 1887.

Sydney Gazette various dates.

Tyerman D. and G. Bennett. Voyages and travels around the world 1821.29. London, 1840. 